\title{
Geochemical evidence of oceanic iron fertilization by the Kasatochi volcanic eruption in 2008 and the potential impacts on Pacific sockeye salmon
}

\author{
N. Olgun ${ }^{1,2,7, *}$, S. Duggen ${ }^{3}$, B. Langmann ${ }^{4}$, M. Hort ${ }^{4}$, C. F. Waythomas ${ }^{5}$, \\ L. Hoffmann ${ }^{2}$, P. Croot $^{6}$ \\ ${ }^{1}$ Dynamics of the Ocean Floor Division, Helmholtz Centre for Ocean Research Kiel (GEOMAR), 24105 Kiel, Germany \\ ${ }^{2}$ Marine Biogeochemistry Division, Helmholtz Centre for Ocean Research Kiel, (GEOMAR), 24148 Kiel, Germany \\ ${ }^{3}$ A. P. Møller Skolen, Upper Secondary School and Sixth Form College of the Danish National Minority in Northern Germany, \\ 24837 Schleswig, Germany \\ ${ }^{4}$ Institute of Geophysics, University of Hamburg, Klima Campus, 20146 Hamburg, Germany \\ ${ }^{5}$ US Geological Survey Alaska Volcano Observatory, Anchorage, Alaska 99508, USA \\ ${ }^{6}$ Earth and Ocean Sciences Department, National University of Ireland, Galway, Ireland
}

${ }^{7}$ Present address: Eurasia Institute of Earth Sciences, Istanbul Technical University, 34469 Istanbul, Turkey

\begin{abstract}
The Kasatochi volcanic eruption that occurred in the central Aleutian Islands in Alaska, USA, in August 2008 is thought to have induced a massive diatom bloom in the ironlimited waters of the Gulf of Alaska, which potentially affected the oceanic food web by increasing the abundance of zooplankton and sockeye salmon Oncorhynchus nerka in the northeast Pacific Ocean. We report the first seawater experiments involving volcanic ash ejected from the Kasatochi eruption, showing that the ash released 61 to $83 \mathrm{nmol} \mathrm{Fe}, 374$ to $410 \mathrm{nmol} \mathrm{NO}{ }^{-}, 5$ to $6 \mathrm{nmol}$ $\mathrm{PO}_{4}{ }^{3-}$ and 170 to $585 \mathrm{nmol} \mathrm{SiO}_{2}$ when it contacted seawater. Our study suggests that the amount of iron released from Kasatochi ash (an increase of 2.0 to $2.8 \mathrm{nM} \mathrm{Fe}$ ) was indeed sufficient to cause the observed phytoplankton bloom in the northeastern Pacific Gyre, while the impact of macronutrient release was minimal. We further evaluated the multiple, interdependent processes in the oceanic food web related to the diatom bloom, involving the ocean survival of juvenile salmon that entered the northeast Pacific Ocean in the summer of 2008.
\end{abstract}

KEY WORDS: Kasatochi eruption · Volcanic ash · Fe limitation · Diatom bloom · Gulf of Alaska · Sockeye salmon

Resale or republication not permitted without written consent of the publisher

\section{INTRODUCTION}

Volcanic ash ejected during explosive volcanic eruptions can be transported several hundreds of kilometers in the atmosphere and deposited in the remote ocean, where nutrient levels in the surface ocean limit marine primary productivity. Upon interaction with seawater, volcanic ash releases several biologically relevant elements into the seawater (Frogner et al. 2001, Duggen et al. 2007, Jones \& Gislason 2008, Olgun et al. 2011, 2013) which may affect phytoplankton growth (Censi et al. 2010, Hamme et al. 2010, Langmann et al. 2010b, Lin et al. 2011, Hoffmann et al. 2012). Some eruptions can negatively affect the marine environment by releasing acidic aerosols and thus reducing the $\mathrm{pH}$ of the seawater (Wall-Palmer et al. 2011), or releasing toxic metals (e.g. $\mathrm{Cu}$ ) in high concentrations (Frogner Kockum et al. 2006, Hoffmann et al. 2012).

The northeast Pacific Ocean is a high-nutrient, low-chlorophyll (HNLC) ocean region where phytoplankton growth is known to be limited by Fe (Martin 
\& Fitzwater 1988, Boyd \& Harrison 1999), and sporadically by Si (Wong \& Matear 1999, Whitney et al. 2005). It is one of the most volcanically active regions on Earth, containing more than 150 subaerial volcanoes in the Kurile-Kamchatka and Aleutian volcanic arcs, which produce about 10 volcanic eruptions each year (Siebert \& Simkin 2002). Due to the high flux of volcanic ash in the North Pacific Ocean, atmospheric deposition of volcanic ash has been considered to be an important external Fe source in the region (Olgun et al. 2011). The fertilizing potential of volcanic eruptions has been previously observed in the North Pacific Ocean region after the eruptions of Miyake-Jima in 2000 and Anatahano in 2003 (Uematsu et al. 2004, Lin et al. 2011), and also in the neighboring rivers and lakes during the Mount St. Helens eruption in 1980 (Smith \& White 1985).

During July-August 2008, 3 explosive volcanic eruptions occurred in the remote Aleutian Islands of Alaska: at Okmok on 12 July, Cleveland on 21 July, and Kasatochi on 7 to 8 August (Waythomas et al. 2008, Larsen et al. 2009, Langmann et al. 2010b). The Kasatochi volcanic eruption was the largest of the 3 eruptions, producing several ash plumes that reached as high as $18 \mathrm{~km}$ above the sea level (Langmann et al. 2010a, Waythomas et al. 2010). An un- usual and extensive phytoplankton bloom (covering an area of ca. $1.5 \times 10^{6} \mathrm{~km}^{2}$ ) started in the Gulf of Alaska a few days after the Kasatochi eruption (Fig. 1), and this bloom has been related to Fe-fertilization by Kasatochi ash fallout (Hamme et al. 2010, Langmann et al. 2010b). The mean chlorophyll a (chl a) values in August 2008 were 2 to 3 times higher than the usual values for this time of year (Hamme et al. 2010).

The phytoplankton bloom that started a few days after the eruption was detectable by satellite images for over $2 \mathrm{mo}$, until the end of September 2008 (Hamme et al. 2010, Langmann et al. 2010b). Two years after the Kasatochi eruption, a record number (35 million) of sockeye salmon Oncorhynchus nerka returned to the Fraser River in Canada (Larkin 2010), causing scientists to speculate about possible reasons behind this dramatic number - including the effects of the volcanic eruption (Parsons \& Whitney 2012).

Other potential nutrient sources in the region, such as wind-blown dust from Asian deserts or mesoscale eddies (which can provide nutrients from deep water), were lacking during the time of the diatom bloom; supporting the speculation of a link between the Kasatochi ash fallout and the subsequent phytoplankton bloom in the eastern North Pacific (Hamme

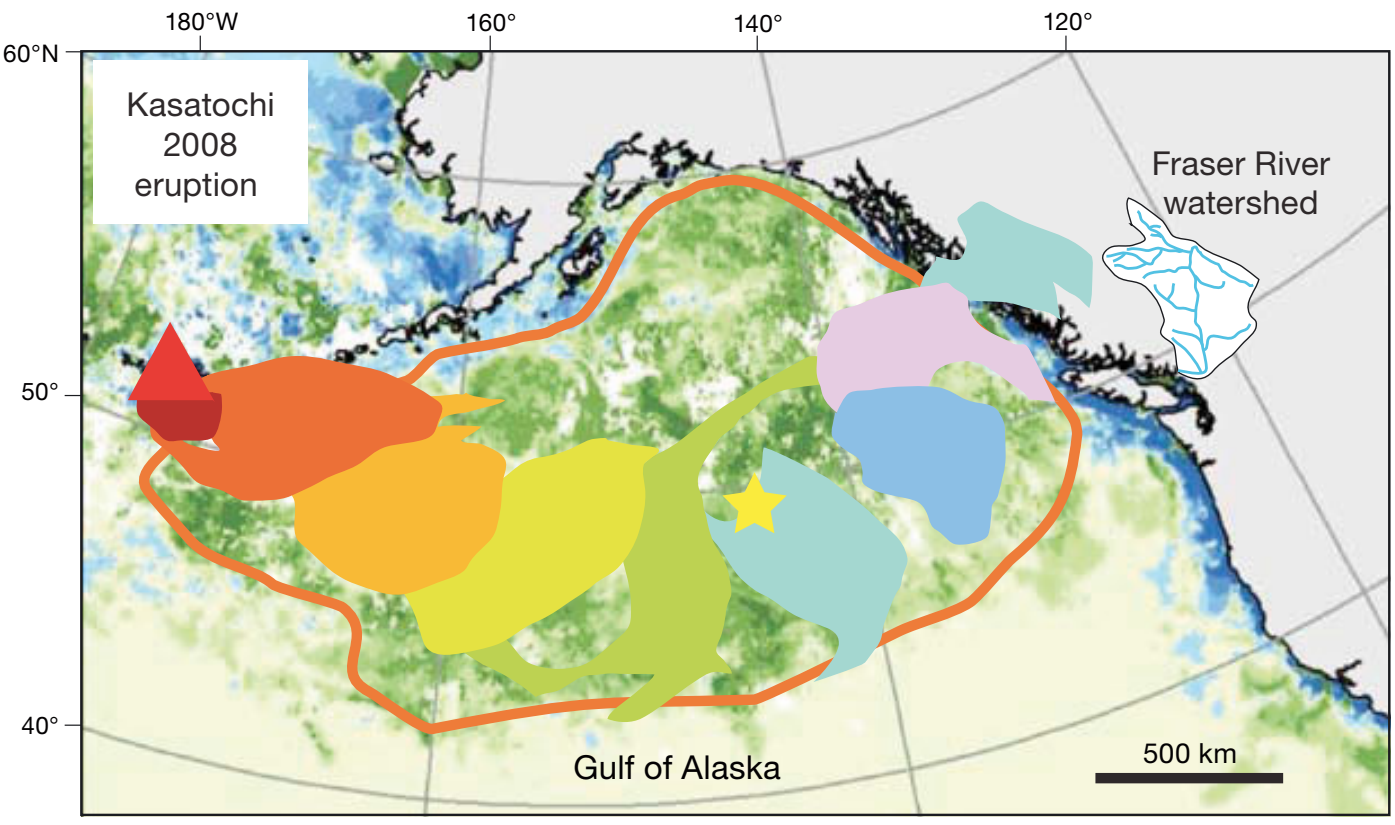

Chlorophyll a difference ( $\mathrm{mg} \mathrm{m}^{-3}$ ) (August 2008)-(August 2002-2007)

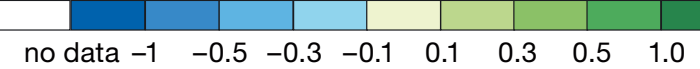

Position of the ash cloud between 8-11 August 2008 (hours after the eruption)

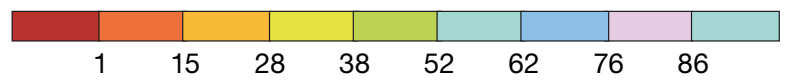

Fig. 1. MODIS-Aqua map based on Langmann et al. (2010b) showing relative increase in chlorophyll a concentrations in $\mathrm{Au}-$ gust 2008, most likely related to the Kasatochi (red triangle) volcanic eruption on 7 and 8 August 2008 . The position of the ash cloud is shown in the colored areas. The bloom area is indicated by a red line. Chlorophyll a concentrations are the monthly mean August 2008 minus the background monthly mean in the last $6 \mathrm{yr}$ (from August 2002 to August 2007). Also shown are the location of Ocean Station Papa (yellow star at $50^{\circ} \mathrm{N}$, $145^{\circ} \mathrm{W}$ ) and the Fraser River watershed area on the Pacific coast of Canada 
et al. 2010, Langmann et al. 2010b). However, this possible link remained speculative as it was unknown if the Kasatochi eruption released sufficient amounts of $\mathrm{Fe}$ into the seawater. We present data from $\mathrm{Fe}$ - and macronutrient-dissolution experiments conducted using volcanic ash from the Kasatochi 2008 eruption. We further discuss the potential oceanic food-web dynamics affected by the Kasatochi eruption that might have influenced the salmon population in 2010 in the northeastern Pacific Ocean and also the neighboring rivers in the USA and Canada.

\section{MATERIALS AND METHODS}

Most of the volcanic ash ejected during the Kasatochi eruption was deposited in the ocean (Waythomas et al. 2010). Deposits on the Kasatochi and neighboring islands, which were readily available, had been exposed to rain and were wet when sampled (Waythomas et al. 2010). A fishing boat transiting the area during the eruption on 7 August, about $13 \mathrm{~km}$ southwest of the Kasatochi Island, received heavy ash fall. Crew members on the boat collected dry samples and provided them to the Alaska Volcano Observatory. The sample analyzed in the present study came from this fishing boat (Waythomas et al. 2010). The grain size of the sample was relatively coarse, and composed of particles greater than ash size (ash size is $<2 \mathrm{~mm}$ ). We wished to analyze the fine fraction of the tephra deposit, and separated the coarser fraction using $2 \mathrm{~mm}$ metal-free plastic sieves.

The release of Fe from Kasatochi ash was measured by means of cathodic stripping voltammetry (CSV) following the same method previously used by Duggen et al. (2007) and Olgun et al. (2011). Seawater samples used in the Fe-release experiments were from the eastern equatorial Atlantic Ocean, collected during Meteor cruise M68-3. The $\mathrm{pH}$ of the seawater was buffered at $\mathrm{pH} 8.0$ by using $200 \mu \mathrm{l}$ 4-(2-hydroxyethyl)-1-piperazinepropanesulfonic acid (EPPS) $\mathrm{pH}$ buffer at the clean laboratory. An artificial Fe-binding organic ligand $(20 \mu \mathrm{l}$ of TAC) was added to the seawater before the measurements (Croot \& Johansson 2000). An ash sample (50 mg) was added into $200 \mu \mathrm{l}$ seawater (mixing ratio of $2.5 \mathrm{~g} \mathrm{l}^{-1}$ ) and the measurements were done in situ in seawater using CSV. The measurements were done for 3 sub-samples (Fig. 2). The net release of Fe was converted to release in nanomoles $\mathrm{g}^{-1}$ of Kasatochi ash (Fig. 2).

The release of $\mathrm{NO}_{3}{ }^{-}, \mathrm{NH}_{4}{ }^{+}, \mathrm{NO}_{2}{ }^{-}, \mathrm{PO}_{4}{ }^{3-}$ and $\mathrm{SiO}_{2}$ was performed by leaching experiments: $1 \mathrm{~g}$ of ash was added to $50 \mathrm{ml}$ of Atlantic seawater in $60 \mathrm{ml}$

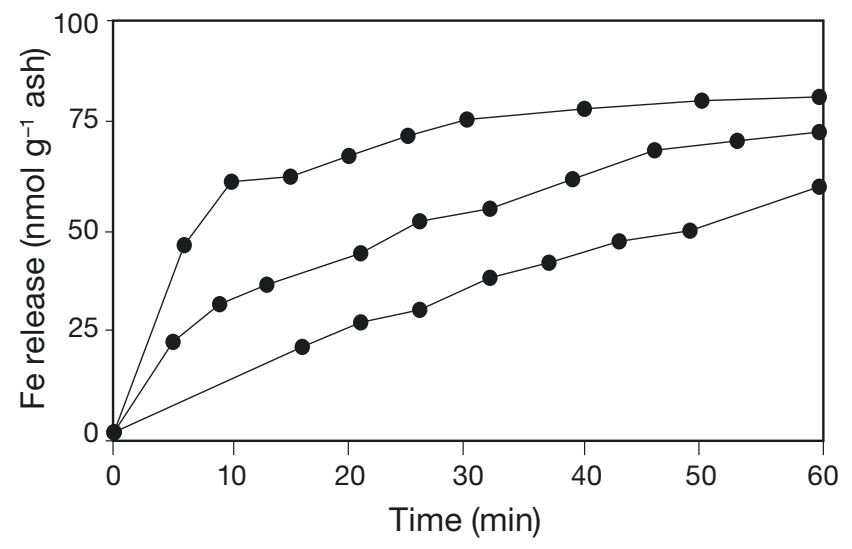

Fig. 2. Release of Fe from volcanic ash from the Kasatochi 2008 eruption in natural seawater over time. The 3 lines represent measurements of 3 sub-samples from the same volcanic ash sample. Measurements were done using cathodic stripping voltammetry

Nalgene Polyprohylene plastic bottles (mixing ratio of $20 \mathrm{~g} \mathrm{l}^{-1}$ ) and shaken gently for about $20 \mathrm{~min}$ and then agitated for $1 \mathrm{~h}$ or $20 \mathrm{~h}$ in seawater. The solutions were later filtered rapidly through a $5 \mu \mathrm{m}$ mesh plastic filter (PTFE Sartious). Macronutrient concentrations in seawater were measured by standard routine photometry. The measured concentrations were converted to the release of nutrient in nanomoles $\mathrm{g}^{-1}$ of Kasatochi ash (Table 1). Total fixed nitrogen was expressed as $\mathrm{NO}_{3}{ }^{-}$. The release of $\mathrm{NH}_{4}{ }^{+}$and $\mathrm{NO}_{2}{ }^{-}$ was converted to $\mathrm{NO}_{3}{ }^{-}$by using molecular weights $\left(\mathrm{NH}_{4}{ }^{+}=32.01 \mathrm{~g} \mathrm{~mol}^{-1}, \mathrm{NO}_{2}^{-}=60.01 \mathrm{~g} \mathrm{~mol}^{-1}, \mathrm{NO}_{3}{ }^{-}=\right.$ $76.01 \mathrm{~g} \mathrm{~mol}^{-1}$ ). The measured concentrations of macronutrients were converted to the release of nutrient in nanomoles $\mathrm{g}^{-1}$ of Kasatochi ash (Table 1).

\section{RESULTS}

Fe-release measurements showed that Kasatochi ash mobilized $\sim 61$ to $83 \mathrm{nmol} \mathrm{Fe}{ }^{-1}$ ash within $1 \mathrm{~h}$ of contact with seawater (Fig. 2). This Fe-release range from Kasatochi ash is in the lower third of the range ( 35 to $340 \mathrm{nmol} \mathrm{g}^{-1}$ ash) for ash from subduction zone volcanoes like Kasatochi (Duggen et al. 2007, Olgun et al. 2011). The results of the macronutrient experiments showed that within the first hour of contact with seawater, Kasatochi ash released $374 \mathrm{nmol} \mathrm{NO}_{3}{ }^{-}$ (as total fixed-N), $5 \mathrm{nmol} \mathrm{PO}_{4}{ }^{3-}$ and $170 \mathrm{nmol}$ of $\mathrm{SiO}_{2}$ $\mathrm{g}^{-1}$ ash (Table 1). After $20 \mathrm{~h}, 410 \mathrm{nmol} \mathrm{NO}_{3}{ }^{-}, 6 \mathrm{nmol}$ $\mathrm{PO}_{4}{ }^{3-}$ and $585 \mathrm{nmol}$ of $\mathrm{SiO}_{2}$ were released per gram of ash (Table 1). The highest leaching rates were seen for $\mathrm{NO}_{3}{ }^{-}$and $\mathrm{SiO}_{2}$, while the concentration of $\mathrm{PO}_{4}{ }^{3-}$ stayed constant during the $20 \mathrm{~h}$ experiment. The data 
Table 1. Estimated new supply of nutrients in the northeast Pacific Ocean related to the Kasatochi volcanic ash fallout in August 2008, based on the nutrient release from Kasatochi ash into seawater

\begin{tabular}{|c|c|c|c|}
\hline & $\begin{array}{l}\text { Release of nutrients } \\
\text { from Kasatochi ash } \\
\text { (nmol g }{ }^{-1} \text { ash) }\end{array}$ & $\begin{array}{l}\text { Initial seawater concentrations } \\
\text { in the northeast Pacific Ocean } \\
(\mathrm{nM})\end{array}$ & $\begin{array}{l}\text { New supply of nutrients } \\
\text { by the Kasatochi ash fallout } \\
(\mathrm{nM})^{\mathrm{c}}\end{array}$ \\
\hline $\mathrm{Fe}$ & $61-83$ & $<0.05^{\mathrm{a}}$ & $2.0-2.8^{\mathrm{d}}$ \\
\hline $\mathrm{NO}_{3}{ }^{-}$ & $374-410$ & $5000-10000^{\mathrm{b}}$ & $13-14$ \\
\hline $\mathrm{PO}_{4}{ }^{3-}$ & $5-6$ & $100-1000^{\mathrm{b}}$ & $<0.2$ \\
\hline $\mathrm{SiO}_{2}$ & $170-585$ & $5000-15000^{\mathrm{b}}$ & $6-20$ \\
\hline \multicolumn{4}{|c|}{$\begin{array}{l}\text { aSource: Nishioka et al. (2001) } \\
{ }^{\text {b} S o u r c e: ~ L e v i t u s ~ e t ~ a l . ~(1994), ~ D e ~ B a a r ~ \& ~ D e ~ J o n g ~(2001), ~ T s u d a ~ e t ~ a l . ~(2003), ~ B o y d ~ e t ~ a l . ~(2007) ~} \\
\text { cBased on the nutrient release from Kasatochi ash calculated over the fertilized area of } 1.5 \times 10^{6} \mathrm{~km}^{2} \text { in the Gulf of Alaska } \\
\text { (Fig. 1) and a mixed layer of } 20 \mathrm{~m} \text { (www.pac.dfo-mpo.gc.ca/science/oceans/data/projects/argo/MLD/Mld2784.gif) } \\
\text { dAbove the threshold (of } 2 \mathrm{nM} \mathrm{Fe)} \mathrm{for} \mathrm{stimulating} \mathrm{diatom} \mathrm{bloom} \mathrm{in} \mathrm{the} \mathrm{Fe-limited} \mathrm{regions} \mathrm{(Wells} \mathrm{2003)}\end{array}$} \\
\hline
\end{tabular}

likely reflect a minimum, since the ash sample was coarse and collected near the Kasatochi volcano (i.e. within $13 \mathrm{~km}$ ). Small particle size and interaction with cloud water during atmospheric transportation could enhance the solubility of surface compounds, and enhance the nutrient release of volcanic ash particles in the seawater (Duggen et al. 2010).

\section{DISCUSSION}

\section{Potential nutrient supply by Kasatochi volcanic ash fallout}

The background macronutrient concentrations in the eastern North Pacific range between 5-10 $\mu \mathrm{M}$ $\mathrm{NO}_{3}{ }^{-}, 0.1-1 \mu \mathrm{M} \mathrm{PO}_{4}{ }^{3-}$ and 5-15 $\mu \mathrm{m} \mathrm{SiO}_{2}$ (Levitus et al. 1994, De Baar \& De Jong 2001, Tsuda et al. 2003, Boyd et al. 2007), whereas dissolved Fe concentrations are very low $(<0.05 \mathrm{nM}$ ) (Levitus et al. 1994, Nishioka et al. 2001). External input of even nanomolar amounts of Fe can therefore have large impacts on marine primary production in the Fe-depleted waters of the northeast Pacific Ocean. The large increase in the phytoplankton stock would be accompanied by strong utilization of macronutrients, to a greater extent in the North Pacific than in other HNLC regions (Tsuda et al. 2003). A high demand for silica in the fertilized region of the eastern North Pacific was evidenced by reduced silicic acid concentrations during August 2008 (Hamme et al. 2010).

The increase of nutrient levels in the ash-fertilized region can be inferred from combining these new data (Table 1) with constraints for the erupted mass of $\sim 10^{15} \mathrm{~g}$ ash based on a 1-dimensional volcanic mo- del (Langmann et al. 2010b), the area of the ash fall region of $1.5 \times 10^{6} \mathrm{~km}^{2}$ (Fig. 1), and the ocean mixed layer depth of $20 \mathrm{~m}$ (www.pac.dfo-mpo.gc.ca/ science/oceans/data/projects/argo/MLD/Mld2784.gif). The major error in the nutrient supply estimates comes from the actual volume of the ash deposit, which is unknown since most of the ash was deposited in the ocean. Satellite data indicate ash aloft over a broad area (Hamme et al. 2010, Langmann et al. 2010a,b), but this does not mean that the ash fallout occurred in the same area, and the ash fallout would have been non-uniform over the fertilized area. Also, the maximum increase in the Fe concentrations that could be reached in the surface ocean depends to a large extent on the biogeochemical controls of the seawater such as Fe-binding ligands (Gerringa et al. 2006, Baker \& Croot 2010).

Assuming a homogenous distribution of ash over the $20 \mathrm{~m}$ mixed layer, our calculations suggest that the deposition of Kasatochi ash might have added 2.0 to $2.8 \mathrm{nM}$ Fe to the ash fall region in the northeast Pacific (Table 1). Mesoscale Fe-enrichment experiments demonstrate that an increase of about 2 to $3 \mathrm{nM} \mathrm{Fe}$ is enough to trigger diatom blooms in HNLC regions (Tsuda et al. 2003, Wells 2003), suggesting that Fe input from the Kasatochi ash was sufficient to stimulate the massive phytoplankton bloom in the Gulf of Alaska (Hamme et al. 2010, Langmann et al. 2010a,b).

Our estimates of the new supply of macronutrients related to the volcanic ash fall in the region are 13 to $14 \mathrm{nM} \mathrm{NO}_{3}{ }^{-},<0.2 \mathrm{nM} \mathrm{PO}_{4}{ }^{3-}$ and 6 to $20 \mathrm{nM} \mathrm{SiO}_{2}$ (Table 1). Background concentrations of macronutrients (Table 1) in the North Pacific are significantly higher compared to the estimated new supply as a re- 
sult of the Kasatochi ash fall, suggesting that the impact of macronutrients released from Kasatochi ash on marine primary productivity was probably minimal. Volcanic ash releases a variety of trace metals such as $\mathrm{Al}, \mathrm{Cd}, \mathrm{Co}, \mathrm{Cu}, \mathrm{Mn}, \mathrm{Ni}, \mathrm{Pb}$ and $\mathrm{Zn}$ (Frogner Kockum et al. 2006, Duggen et al. 2007, Jones \& Gislason 2008, Hoffmann et al. 2012). The combined effects of an array of elements released by volcanic ash can also vary depending on the phytoplankton species. A recent study suggests that the growth rate of the diatom Thalassiosira pseudonana was significantly increased in culture experiments due to a combination of different trace metals released from volcanic ash, rather than of Fe alone (Hoffmann et al. 2012). It is therefore possible that other trace metals besides $\mathrm{Fe}$ might have also influenced the phytoplankton growth in the surface ocean.

Ship-board measurements in the southern part of the bloom area showed that the phytoplankton was dominated by large diatoms (Hamme et al. 2010), similar to previous observations in the northeastern Pacific during Fe-enrichment incubation experiments (Boyd et al. 1996). Diatoms significantly contribute to the carbon uptake in the global ocean. Based on the $\mathrm{pCO}_{2}$ decrease (of $25 \mu \mathrm{atm}$ ) at the Ocean Station Papa (Fig. 1), the $\mathrm{C}$ drawdown in August 2008 associated with the diatom bloom (extrapolated over the fertilized area) has been calculated to be $\sim 6$ to $17 \times$ $10^{12} \mathrm{~g} \mathrm{C}$ (Hamme et al. 2010). Given a typical C:Fe ratio of $10^{4}$ for Fe uptake under 1 to $3 \mathrm{nM}$ Fe concentrations (Sunda \& Huntsman 1995), the C drawdown based on the new Fe-release data (Fig. 2) is 34 to $46 \times$ $10^{12} \mathrm{~g} \mathrm{C}$, which is about 3 to 6 times higher than of the actual estimated C drawdown (Hamme et al. 2010). Considering the uncertainties related to the precipitation and complexation of $\mathrm{Fe}$ and utilization by other phytoplankton groups and bacteria, the actual C drawdown related to the North Pacific bloom (Hamme et al. 2010) could be derived by the Fe input from Kasatochi volcanic ash fallout.

\section{Sockeye salmon population could have benefited from the 2008 Kasatochi volcanic eruption}

In August-September 2008, there was an unusual increase in mesozooplankton (dominated by large copepods) in the bloom area in the northeast Pacific (Hamme et al. 2010). This increased abundance of larger copepods has been connected to the diatom bloom, which allowed the zooplankton to feed closer to the surface (Hamme et al. 2010). Juvenile sockeye salmon feed extensively on zooplankton - preferen- tially larger zooplankton (Foerster 1968) - which were abundant in the bloom region (Hamme et al. 2010). In 2010, about 35 million sockeye returned to the Fraser River in British Columbia (Canada). This was the largest return of salmon since 1913, and about 17 times higher than the average (Larkin 2010). This enigmatic number of Fraser River sockeye returns has been linked to favorable food conditions related to the oceanic fertilization by the Kasatochi eruption, which may have increased the marine survival of juvenile sockeye that entered the ocean in summer 2008 (Parsons \& Whitney 2012).

Most sockeye salmon have a 4 yr life cycle, spending $2 \mathrm{yr}$ in fresh water and $2 \mathrm{yr}$ in the ocean before returning to nursery rivers to spawn and die (Foerster 1968, Cass \& Wood 1994). The timing of the diatom bloom matches with the ocean migration of sockeye (between July and October), considered to be one of the most critical life stages of sockeye salmon (Hartt 1980, Furnell \& Brett 1986). Sockeye salmon originating from British Columbia, Washington State and southeast Alaska migrate out directly into the northeast Pacific and the Gulf of Alaska, while salmon originating from Bristol Bay migrate first across the Bering Sea to areas close to Kamchatka and south of the Aleutian Islands (Burgner 1991). A fall bloom in the Gulf of Alaska is likely to impact the British Columbia sockeye to a higher extent than Bristol Bay sockeye.

Young salmon released into the zooplankton bloom survived better compared to those entering the ocean under poor zooplankton conditions (Cross et al. 2008). Favorable food conditions in the ocean can result in increased growth rates of salmon, which can ultimately affect their overall survival (Beauchamp et al. 2007, Duff 2009). The fertilized region in the northeast Pacific is similar to the oceanic region occupied by sockeye salmon (Walter et al. 1997, Parsons \& Whitney 2012). It is therefore very plausible that the diatom bloom related to the Kasatochi eruption, which covered a large part of the feeding area of sockeye salmon, stimulated the ocean food web and provided a food source for zooplankton, thus making the link to the sockeye salmon ocean survival. Coastal conditions around Vancouver Island in summer 2008 may have also played a role in the marine survival of sockeye salmon. It has been suggested that cool water temperatures around Vancouver Island in the summer of 2008 (related to a La Niña event) provided favorable conditions for estuary survival of salmon (DFO 2009).

Although the diatom bloom in late summer 2008 covered a large region in the northeast Pacific 
(Fig. 1), 2010 sockeye river returns were variable along the sockeye harvest regions in the northeast Pacific. In Bristol Bay in central Alaska, the sockeye return in Nushagak River (about 11 million sockeye) was the second highest ever recorded, while sockeye returns in the Egegik River region (about 5 million sockeye) were $45 \%$ below the pre-season forecasts (Eggers \& Carroll 2011). Considerable differences in terms of origin and migration movements of salmon, as well as a number of other factors including the number and size of the smolts that entered the ocean, coastal conditions during ocean entrance, and coastal survival prior to river migration might have also played an important role in the ocean survival of sockeye salmon.

\section{Volcanic eruptions and ecosystem response in the North Pacific Ocean}

Volcanic eruptions may have influenced the marine food web in the North Pacific and neighboring regions in the past (Duggen et al. 2010). Interestingly, one of the largest salmon runs in 1958 (Groot \& Quinn 1987) followed the large eruption of Benzymjanny volcano in Kamchatka that started midNovember 1955 (Gorshkov 1959). It has been suggested that the ash fallout from the 1912 KatmaiNovarupta eruption in Alaska fertilized the nearby lakes (due to ash-derived phosphorus; Eicher \& Rousefell 1957). However, the direct impact of the extreme ash load from this eruption was the initial mortality of pre-smolts in the local rivers caused by damage to the gills of the salmon (Eicher \& Rousefell 1957, Duggen et al. 2010). Despite the smaller number of spawning fish in the rivers and lakes immediately following the Katmai-Novarupta eruption, the numbers of sockeye returning in the following 4 years were as large as pre-eruption, indicating a rapid recovery - possibly associated with favorable ocean conditions (Eicher \& Rousefell 1957).

\section{CONCLUSIONS}

The role of volcanic eruptions in oceanic biogeochemical cycles is still not fully understood, but there is increasing evidence of their significant impact on marine primary production. Our study indicates that Fe released from the Kasatochi volcanic ash was sufficient to induce large-scale phytoplankton blooms, with potential implications for higher trophic levels - in this case, the sockeye salmon population. How- ever, varying ecologic impacts of volcanic ash in fresh waters, in coastal regions and in the open ocean require more scientific attention in order to evaluate their importance for oceanic food web dynamics.

Acknowledgements. This study was supported by GEOMAR-Helmholtz Centre for Ocean Research Kiel, through the multidisciplinary research group NOVUM "Nutrients Originating Volcanoes and their effects on the eUphotic zone of the Marine ecosystem" and contribution number 174 of the Sonderforschungsbereich (SFB) 574 "Volatiles and Hazards in Subduction Zones". We are grateful to Frank Malien (GEOMAR, Kiel) for his assistance during the macronutrient measurements. We thank US Geological Survey Alaska Volcano Observatory for providing the Kasatochi volcanic ash sample.

\section{LITERATURE CITED}

Baker A, Croot P (2010) Atmospheric and marine controls on aerosol iron solubility in seawater. Mar Chem 120:4-13

Beauchamp DA, Cross AD, Armstrong JL, Myers KW, Moss JH, Boldt JL, Haldorson LJ (2007) Bioenergetic responses by Pacific salmon to climate and ecosystem variation. North Pac Anadromous Fish Comm 4:257-269

Boyd P, Harrison PJ (1999) Phytoplankton dynamics in the NE subarctic Pacific. Deep-Sea Res II 46:2405-2432

Boyd PW, Muggli DL, Varela DE, Goldblatt RH, Chretien R, Orians KJ, Harrison PJ (1996) In vitro iron enrichment experiments in the NE subarctic Pacific. Mar Ecol Prog Ser 136:179-193

> Boyd PW, Jickells T, Law CS, Blain S and others (2007) Mesoscale iron enrichment experiments 1993-2005: synthesis and future directions. Science 315:612-617

Burgner RL (1991) Pacific salmon life histories. University of British Columbia Press, Vancouver

> Cass AJ, Wood CC (1994) Evaluation of the depensatory fishing hypothesis as an explanation for population cycles in Fraser River sockeye salmon (Oncorhynchus nerka). Can J Fish Aquat Sci 51:1839-1854

Censi P, Randazzo LA, Zuddas P, Saiano F, Aricò P, Andò S (2010) Trace element behaviour in seawater during Etna's pyroclastic activity in 2001: concurrent effects of nutrients and formation of alteration minerals. J Volcanol Geotherm Res 193:106-116

Croot P, Johansson M (2000) Determination of iron speciation by cathodic stripping voltammetry in seawater using the competing ligand 2-(2-Thiazolylazo)- $p$-creasol (TAC). Electroanalysis 12:565-576

$>$ Cross AD, Beauchamp DA, Myers KW, Moss JH (2008) Early marine growth of pink salmon in Prince William Sound and the coastal Gulf of Alaska during years of low and high survival. Trans Am Fish Soc 137:927-939

De Baar HJW, De Jong JTM (2001) Distributions, sources and sinks of iron in seawater. In: Turner DR, Hunter KA (eds) The biogeochemistry of iron in seawater. Wiley, Chicester, p 212-215

DFO (Department of Fisheries and Oceans) (2009) State of the Pacific Ocean 2008. Science Advisory Report 2009/ 030, Fisheries and Oceans Canada, Nanaimo

Duff E (2009) Factors during early marine life that affect smolt-to-adult survival of ocean-type Puget Sound Chi- 
nook salmon (Oncorhynchus tshawytscha). University of Washington, Seattle, WA

Duggen S, Croot P, Schacht U, Hoffmann L (2007) Subduction zone volcanic ash can fertilize the surface ocean and stimulate phytoplankton growth: evidence from biogeochemical experiments and satellite data. Geophys Res Lett 34:L01612, doi:10.1029/2006GL027522

> Duggen S, Olgun N, Croot P, Hoffmann L, Dietze H, Teschner C (2010) The role of airborne volcanic ash for the surface ocean biogeochemical iron-cycle: a review. Biogeosciences 7:827-844

Eggers DM, Carroll AM (2011) Run forecasts and harvest projections for 2011 Alaska salmon fisheries and review of the 2010 season. Alaska Department of Fish and Game, Anchorage, AK

Eicher GJ, Rousefell GA (1957) Effects of lake fertilization by volcanic activity on abundance of salmon. Limnol Oceanogr 2:70-76

Foerster RE (1968) The sockeye salmon, Oncorhynchus nerka. Bulletin of Fisheries Research Board of Canada, Vol 162, Ottawa

> Frogner P, Gislason SR, Óskarsson N (2001) Fertilizing potential of volcanic ash in ocean surface water. Geology 29:487-490

> Frogner Kockum PC, Herbert RB, Grislason SR (2006) A diverse ecosystem response to volcanic aerosols. Chem Geol 231:57-66

> Furnell DJ, Brett JR (1986) Model of monthly marine growth and natural mortality for Babine Lake sockeye salmon (Oncorhynchus nerka). Can J Fish Aquat Sci 43: 999-1004

Gerringa LJA, Veldhuis MJW, Timmermans KR, Sarthou G, de Baar HJW (2006) Co-variance of dissolved Fe-binding ligands with phytoplankton characteristics in the Canary Basin. Mar Chem 102:276-290

- Gorshkov GS (1959) Gigantic eruption of the volcano Bezymianny. Bull Volcanol 20:77-109

Groot C, Quinn TP (1987) Homing migration of sockeye salmon, Oncorhynchus nerka, to the Fraser River. Fish Bull 85:455-469

Hamme RC, Webley PW, Crawford WR, Whitney FA and others (2010) Volcanic ash fuels anomalous plankton bloom in subarctic northeast Pacific. Geophys Res Lett 37:L19604, doi:10.1029/2010GL044629

Hartt AC (1980) Juvenile salmonids in the oceanic ecosystem: the critical first summer. In: McNeil WJ, Himsworth DC (eds) Symposium on salmonid ecosystems of the North Pacific. Oregon State University Press, Corvallis, OR, p 25-57

> Hoffmann L, Breitbarth E, Ardelan MV, Duggen S, Olgun N, Hasselhöv M, Wängberg SA (2012) Influence of volcanic ash and pumice on phytoplankton growth and $\mathrm{Cu}$ ligand production of Thalassiosira pseudonana and Emiliania huxleyi. Mar Chem 132-133:28-33

> Jones MT, Gislason SR (2008) Rapid releases of metal salts and nutrients following the deposition of volcanic ash into aqueous environments. Geochim Cosmochim Acta 72:3661-3680

Langmann B, Zakšek K, Hort M (2010a) Atmospheric distribution and removal of volcanic ash after the eruption of Kasatochi volcano: a regional model study. J Geophys Res 115:D00L06, doi:10.1029/2009JD013298

Langmann B, Zaksek K, Hort M, Duggen S (2010b) Volcanic ash as fertiliser for the surface ocean. Atmos Chem Phys 10:3891-3899
Larkin K (2010) Canada sees shock salmon glut. Nature doi: 10.1038/news.2010.449

Larsen J, Neal C, Webley P, Freymueller J and others (2009) Eruption of Alaska volcano breaks historic pattern. EOS Trans Am Geophys Union 90:173-174

Levitus S, Burgett R, Boyer T (1994) Nutrients NOAA Atlas NESDIS, Vol 3. US Department of Commerce, Washington, DC

Lin II, Hu C, Li YH, Ho TY and others (2011) Fertilization potential of volcanic dust in the low-nutrient low-chlorophyll western North Pacific subtropical gyre: satellite evidence and laboratory study. Global Biogeochem Cycles 25:GB1006, doi:10.1029/2009GB003758

Martin JH, Fitzwater SE (1988) Iron deficiency limits phytoplankton growth in the north-east Pacific subarctic. Nature 331:341-343

Nishioka J, Takeda S, Wong C, Johnson WK (2001) Sizefractionated iron concentrations in the northeast Pacific Ocean: distribution of soluble and small colloidal iron. Mar Chem 74:157-179

Olgun N, Duggen S, Croot PL, Delmelle P and others (2011) Surface ocean iron fertilization: the role of airborne volcanic ash from subduction zone and hotspot volcanoes and related iron-fluxes into the Pacific Ocean. Global Biogeochem Cycles 25:GB4001, doi:10.1029/2009GB003761

Olgun N, Duggen S, Andronico D, Kutterolf S and others (2013) Possible impacts of volcanic ash emissions of Mount Etna on the primary productivity in the oligotrophic Mediterranean Sea: results from nutrient-release experiments in seawater. Mar Chem 152:32-42

Parsons TR, Whitney FA (2012) Did volcanic ash from Mt. Kasatochi in 2008 contribute to a phenomenal increase in Fraser River sockeye salmon (Oncorhynchus nerka) in 2010? Fish Oceanogr 21:374-377

Siebert L, Simkin T (2002) Volcanoes of the world: an illustrated catologue of Holocene volcanoes and their eruptions. Smithsonian Institution, Global Volcanism Program Digital Information Series, GVP-3

Smith MA, White M (1985) Observations on lakes near Mount St. Helens: phytoplankton. Arch Hydrobiol 104:345-363

Sunda WG, Huntsman SA (1995) Iron uptake and growth limitation in oceanic and coastal phytoplankton. Mar Chem 50:189-206

Tsuda A, Takeda S, Saito H, Nishioka J and others (2003) A mesoscale iron enrichment in the western subarctic Pacific induces a large centric diatom bloom. Science 300: 958-961

> Uematsu M, Toratani M, Kajino M, Narita Y, Senga Y, Kimoto T (2004) Enhancement of primary productivity in the western North Pacific caused by the eruption of the Miyake-jima volcano. Geophys Res Lett 31:L06106, doi: 10.1029/2003GL018790

> Wall-Palmer D, Jones MT, Hart MB, Fisher JK and others (2011) Explosive volcanism as a cause for mass mortality of pteropods. Mar Geol 282:231-239

Walter EE, Scandol JP, Healey MC (1997) A reappraisal of the ocean migration pattern of Fraser River sockeye salmon (Oncorhynchus nerka) by individual-based modelling. Can J Fish Aquat Sci 54:847-858

Waythomas CF, Schneider DJ, Prejean SG (2008) The 2008 eruption of Kasatochi volcano, Central Aleutian Islands: reconnaissance observations and preliminary physical volcanology. EOS Trans Am Geophys Union Fall Meeting (Abstract \#A51J-02)

Waythomas CF, Scott WE, Prejean SG, Schneider DJ, 
Izbekov P, Nye CJ (2010) The August 7-8 eruption of Kasatochi volcano, central Aleutian Islands, Alaska. J Geophys Res 115:B00B06, doi:10.1029/2010JB007437

Wells ML (2003) The level of iron enrichment required to initiate diatom blooms in HNLC waters. Mar Chem 82: 101-114

Editorial responsibility: Jana Davis, Annapolis, Maryland, USA
Whitney FA, Crawford DW, Yoshimura T (2005) The uptake and export of Si and N in HNLC waters of the NE Pacific. Deep-Sea Res II 52:1055-1067

Wong CS, Matear RJ (1999) Sporadic silicate limitation of phytoplankton productivity in the subarctic NE Pacific. Deep-Sea Res II 46:2539-2555

Submitted: November 1, 2011; Accepted: May 8, 2013 Proofs received from author(s): July 25, 2013 